\title{
Impact of farm yard manure on cropping cycle in a rainfed agroecosystem of Central Himalaya
}

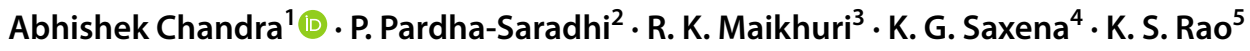

Received: 15 April 2020 / Revised: 5 October 2020 / Accepted: 24 October 2020 / Published online: 3 January 2021

(c) Society for Plant Research 2021

\begin{abstract}
Crops, livestock and forests are interlinked components of Central Himalayan agro-ecosystems. Traditionally, farm yard manure is produced from forest leaf litter and excreta of livestock obtaining $>50 \%$ feed from forests. Chemical fertilizers are not used in rainfed farms on slopes. Experiments were conducted to test whether increase in FYM input rates results improvement in economic and environmental functions of agro-ecosystems. Increase in FYM input rate from $30 \mathrm{t} / \mathrm{ha} / \mathrm{crop}$-season currently practiced by farmers to $60 \mathrm{t} / \mathrm{ha} / \mathrm{crop}$-season showed substantial increase in crop yield and soil quality. Rice and wheat were more responsive to FYM input than the legume black gram. Harvest index is maximum for $60 \mathrm{t} / \mathrm{ha} / \mathrm{crop}$-season FYM treatment for rice and wheat. In blackgram maximum harvest index was obtained when no FYM was provided. During the 3 years of study, soil $\mathrm{pH}$ decreased (becoming more acidic) as compared to that recorded at the start of the study. Soil organic carbon generally declined upto second kharif season and then improved during second rabi (fallow) under no input treatment, and 16t/ha/crop-season FYM treatment and levels of N, P and Mg too showed patterns similar to soil organic carbon, but the trends varied for $\mathrm{Ca}, \mathrm{Na}$ and $\mathrm{K}$. Soils of fields put to 0 and $16 \mathrm{t} / \mathrm{ha} /$ crop-season FYM treatments showed a net decrease in concentration of these elements and those put to 30 and $60 \mathrm{t} / \mathrm{ha} /$ crop-season FYM treatments showed increase in their level.
\end{abstract}

Keywords Rainfed $\cdot$ FYM $\cdot$ Crop-season $\cdot$ Harvest index $\cdot$ Biomass $\cdot$ Yield

\section{Introduction}

Environmental, biological, socio-cultural and economic variation existing in the Central Himalaya have led to the evolution of diverse and unique traditional agro-ecosystems (Lal 2004; Chandra et al. 2010a, b, 2011a; b; Mahanta et al. 2013; Dinakaran et al. 2018). In settled agro-ecosystems on

Abhishek Chandra

ac.india@gmail.com

1 Department of Environmental Sciences, Sri Venkateswara College, University of Delhi, New Delhi 110 021, India

2 Department of Environmental Studies, University of Delhi, New Delhi 110 007, India

3 Department of Environmental Sciences, Hemwati Nandan Bahuguna Garhwal University (The Central University), Garhwal, Srinagar, Uttarakhand 246 174, India

4 School of Environmental Sciences, Jawaharlal Nehru University, New Delhi 110 067, India

5 Department of Botany, University of Delhi, New Delhi 110 007, India terraced slopes, soil fertility is traditionally maintained by incorporation of farm yard manure (FYM) generated from leaf litter collected from the forest floor and excreta of livestock drawing $>50 \%$ of their feed from forests. Traditional practices are fast degenerating and transforming under the influence of multiple factors including lack of analysis of their potential in scientific terms. While inaccessibility and rainfed conditions on terraced slopes have delimited use of chemical fertilizers, increasing labor scarcity arising from diversion of labor to non-farm economic activities and restrictions on utilization of forest resources from diversion of forest land to production of industrial raw material and conservation of biodiversity reduced quality and quantity of farm yard manure. Traditional knowledge is deficient in optimal dozes of farm yard manure, while conventional agricultural scientists have not included exclusive farm yard manure treatment in long term soil fertility experiments (Saxena and Rao 2016). Experiments do show that crop yields are more stable in FYM with chemical fertilizer treatments than exclusive fertilizer treatments (Nambiar 1994; Yadav et al. 1998; Bhandari et al. 2002; Ladha et al. 2003; Kundu et al. 
2007a; Chandra et al. 2011a, b; Bhadauria et al. 2014; Singh et al. 2017; Datta et al. 2018). Farmers often do not pay attention to farm yard manure input because of a conception that nutrient stress (Bhandari et al. 2002; Singh et al. 2004; Kundu et al. 2007b) is not as crucial as wildlife intrusions and climate change in lowering crop yields. Cultivation of crops performing in low soil fertility, fallowing and leasing land are the common ways of coping with the situation (Chandra et al. 2010a, b, 2011a, b, c, 2013; Maikhuri et al. 2015; Rao et al. 2016). The loss of agro-biodiversity and its multiple functions has emerged as major concern at local, regional and national scales in recent period (Negi et al. 2009; Chandra et al., 2011a, b). Increase in farm yard input is likely to increase crop yields by maintaining soil quality (Nayak et al. 2007; Liu et al. 2013; Mahanta et al. 2013; Blanchet et al. 2016; Dinakaran et al. 2019) and also promote forest conservation and restoration for availability of high quality leaf litter and forage. High farm yard manure input based farming in the Himalayan scenario thus reinforces sustainable forest management and carbon sequestration within croplands (Rao et al. 2016).

The present study is an attempt to find out optimal dozes for farm yard manure in rainfed settled agro-ecosystems in Central Himalayan Region of India.

\section{Methods}

\section{General description of experimental site}

A farmer's field plot experiment with the traditional cropping cycle was conducted during April 2003 to May 2006 on rainfed terraced farms in the Langasu-Uttaron village of Chamoli district in the Garhwal Himalaya (30 $17.368^{\prime}$
$\mathrm{N}$ latitude and $77^{\circ} 16.868^{\prime} \mathrm{E}$ longitude). Rainfed cultivated land is mainly on sloping land where irrigation facilities are not available and thus crop cultivation is done using moisture input from rain. Village agricultural land is divide two almost equal halves, "Mulla Sar" below and "Malla Sar" above clustered dwellings. Traditionally, one of these halves is put to fallow in one winter season over two years. Typical cropping sequence in a Sar is: kharif crop (first crop season)—rabi crop (second crop season) - kharif crop (third crop season) - fallow. Thus, second rabi season (fourth crop season) is put to fallow (Chandra 2007; Chandra et al. 2010a, b, 2011a; b).

The parent soil material is represented by feldspathic quartz schist, quartz muscovite schist and chlorite schist and can be classified as Dystric cambisol according to FAO soil classification system (Semwal and Maikhuri 1996). Farmers generally apply FYM @ 30-35 t/ha during first kharif for growing rice, 12-16 t/ha during first rabi for growing wheat and no FYM for growing pulses during second kharif (Chandra et al. 2011a, b; Dinakaran et al. 2019). Daily rainfall $(\mathrm{mm})$, relative humidity $(\%)$, minimum and maximum atmospheric temperature and soil temperature during study period were recorded with help of rain gauge, humidity meter and thermometers. Barring April, November and December, the study area did not suffer from moisture stress as it received sufficient rains in all other months (Figs. 1,2).

\section{Experimental design}

The cropping sequence commenced in the month of April, 2003 on Mullasar with rice followed by wheat (October 2003-May 2004), black gram (June-September 2004), fallow (October 2004-April 2005), rice (April-September 2005) and wheat (October 2005-May 2006) (Fig. 3).

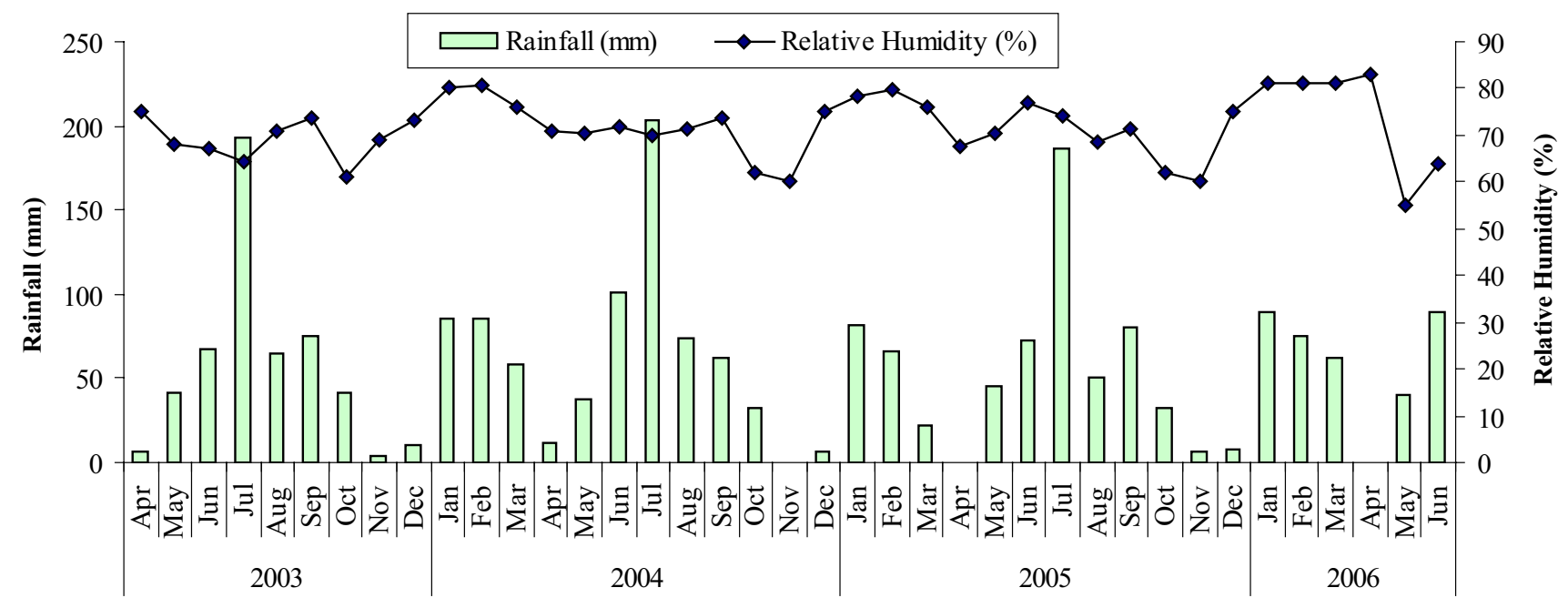

Fig. 1 Monthly rainfall (mm) and relative humidity (\%) at village Langasu-Uttaron, Chamoli district, Garhwal Himalaya, India 


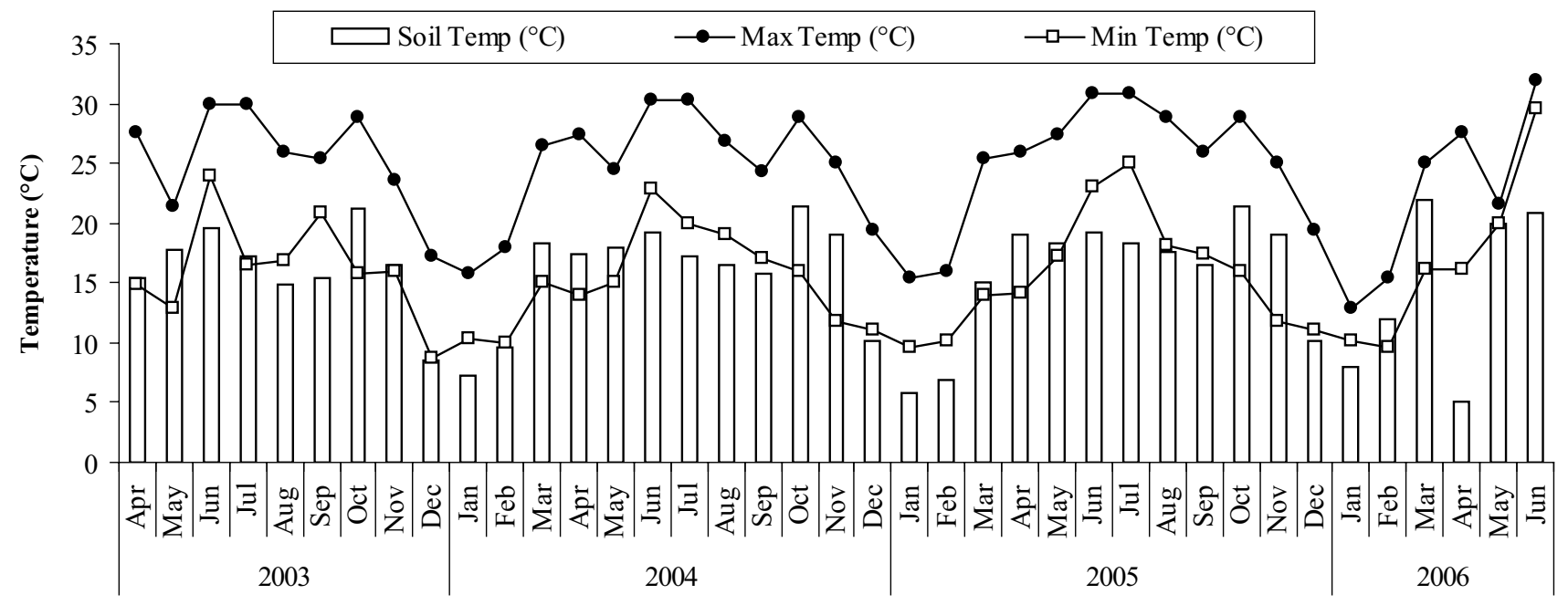

Fig. 2 Minimum and maximum atmospheric temperature and soil temperature $\left({ }^{\circ} \mathrm{C}\right)$ during study period at village Langasu-Uttaron, Chamoli district, Garhwal Himalaya, India

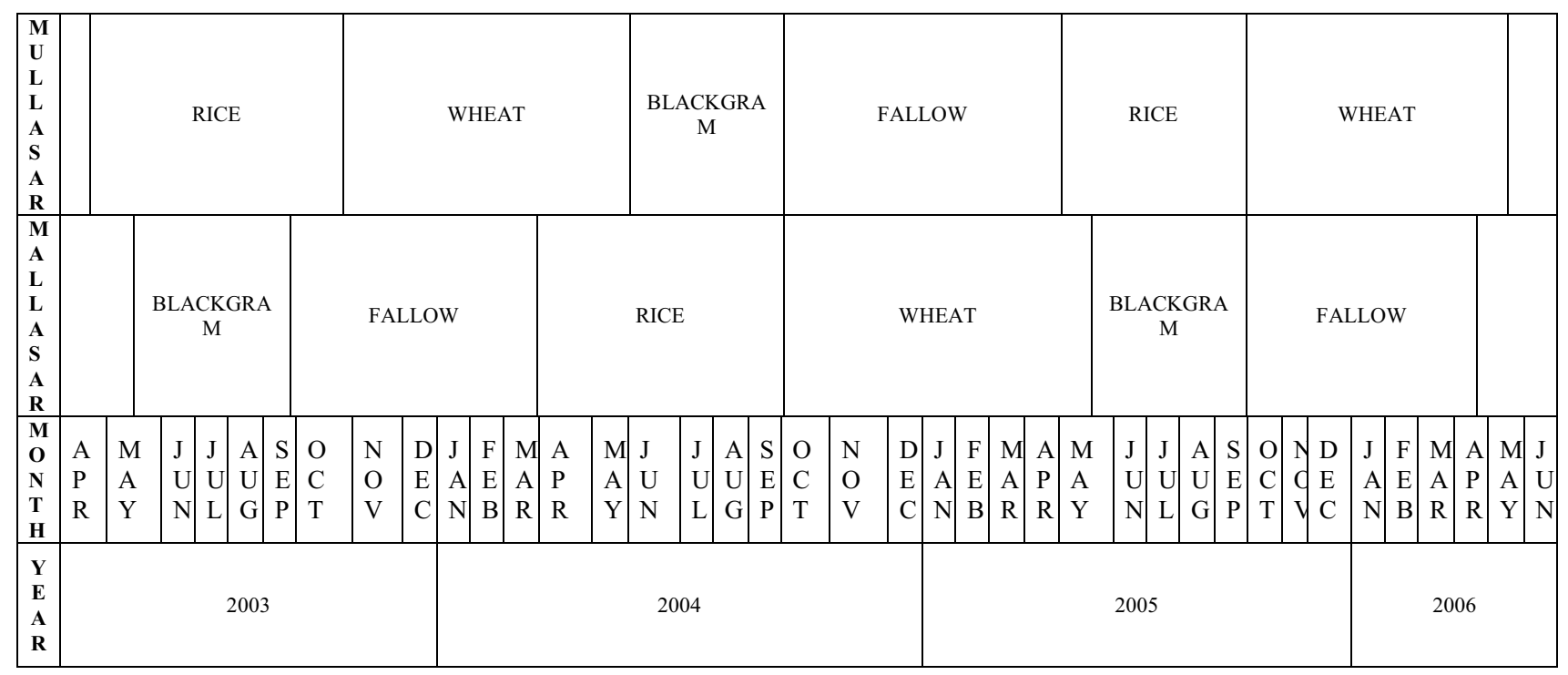

Fig. 3 Crop calendar of experiment under various treatment of FYM

Similarly, on Mallasar the cropping sequence commenced with black gram (May-September 2003) followed by the fallow period (October 2003-April 2004), rice (April-September 2004), wheat (October-May 2004), black gram (May 2005-September 2005) and fallow period (October 2005-April 2006) (Fig. 3).

For assessing the effect of FYM a simple experiment was performed in farmer's field in $3 \times 3$-m plots. A total 12 plots (three replicates per treatment) were established. These plots were separated from each other by one-meter distance. Care was taken to ensure similar topographic conditions to minimize the errors in analysis. FYM was applied @ 0, 16,
30, $60 \mathrm{t} / \mathrm{ha}$ (fresh weight) at the time of ploughing in each crop season.

\section{Crop management}

\section{Seed sowing}

Rice, wheat and black gram were sown in April (first kharif), October (first rabi) and June (second kharif), respectively. Sowing was done after ploughing and land preparation activities. Seed input @ $30 \mathrm{~kg} / \mathrm{ha}$ was decided on the basis of prior discussions with farmers practicing traditional 
cropping for decades. Density of plants was maintained by thinning the plants from the crowded places after 15 days of seed germination. Care was taken to uproot thin and weak plants during the thinning operation.

\section{Weeding}

Weeds were removed by hand thrice, twice and once in rice, wheat and black gram plots, respectively.

\section{Harvesting}

Rice was harvested in September, wheat in April and blackgram in October. The harvest was done manually using a sickle. The plants were cut just a little above the ground level and heaped in the field for drying. The harvested produce of each plot was collected separately, tied into bundles and labelled. The produce of each plot was weighed by a spring balance. After harvesting each plot was hoed to pull out the roots. These roots were pooled and weighed in field.

\section{Threshing and winnowing}

The sun dried produce of each plot was threshed manually by rubbing ears with feet for rice and beating with help of wooden stick over a hard surface for wheat and black gram. Seeds were separated from chaff and cleaned by hand fan (Soopa). Finally, the clean seeds obtained from each plot were weighed on a spring balance.

\section{Dry matter}

$100 \mathrm{gm}$ of shoot, root and grain from each plot were sun dried, packed and labelled. These packets were carried to the laboratory and kept in an oven at $60 \pm 2{ }^{\circ} \mathrm{C}$ for $72 \mathrm{~h}$ or until they attained constant weight. The oven dry weights of different components of crop were recorded on an electronic balance.

\section{Soil sampling and analysis}

Soil sampling was carried out at depth of $0-30 \mathrm{~cm}$ prior to the initiation of the experiment in both the "Sars" and after harvesting of each crop in both kharif and rabi seasons. i.e., in the months of April/May and October/November, respectively. Soil was sampled from five random locations in each of the three replicate plots. Samples from each plot were mixed thoroughly to obtain one composite sample per plot. Soil pH was measured following Jackson (2005). Soil organic carbon content was determined by the method of Walkley and Black (1934). Organic carbon free soil samples were used to determine total $\mathrm{N}, \mathrm{K}, \mathrm{Ca}, \mathrm{Mg}, \mathrm{Na}$ and available $\mathrm{P}$. The digestions were carried out using Kjeldhal apparatus
(Anderson and Ingram 1989). Total $\mathrm{N}$ was estimated by micro- Kjeldhal method (Allen 1974). Available phosphorous was measured at $880 \mathrm{~nm}$ wavelength using ammonium molybdate blue menthod (Systronics 160). Total calcium $(\mathrm{Ca})$, magnesium $(\mathrm{Mg})$, sodium $(\mathrm{Na})$ and potassium $(\mathrm{K})$ were estimated using the same filtrate by atomic absorption spectrophotometry (AA 6300 Shimadzu, Japan).

\section{Harvest index, equivalent rice yield and protein}

Harvest Index (HI) was computed following Mandal et al. (2009), equivalent rice yield Rautaray et al. (2003) and Protein content following Singh et al. (2002) and Gopalan et al. (2004).

\section{Statistical analysis}

Analysis of variance across years (Gomez and Gomez 1984) was performed to determine the effects of treatment, year, and their interactions on productivity and simple student $t$ test-paired two samples for mean $(P<0.05)$ were used to compare different soil and plant parameters between different seasons and treatment using Microsoft Excel.

\section{Results}

Production of roots, shoots and grains in rice, wheat and black gram increased with increase in the FYM input in both the "Sars". Overall, yields were highest in $60 \mathrm{t} / \mathrm{ha} /$ crop-season FYM treatment and lowest in control (no FYM application). Highest harvest index was recorded in $60 \mathrm{t} / \mathrm{ha} /$ crop-season FYM treatment in rice and wheat but in control (no FYM input), in black (Tables 1,2).

In general, there was no significant variation in the yield across years and FYM input rates. While the harvest index was quite stable in rice, it varied substantially in wheat indicating that this crop was quite sensitive to FYM input rates and year-to-year variations in climatic conditions determining soil moisture in rainfed conditions. Blackgram, like rice, also did not show any significant variation in harvest index with variation in FYM rates or year-to-year variation in climatic conditions (Fig. 4).

Grain yield of rice, wheat, blackgram or total yield of cropping sequence did not show any significant $(P>0.05)$ variation between Mullasar and Mallasar. Rice biomass under FYM treatment of $16 \mathrm{t} / \mathrm{ha} / \mathrm{crop}$-season varied significantly $(\mathrm{P}<0.05)$ between the two Sars. In all other cases, no significant variation in total biomass production was recorded between the two Sars. Significant difference $(\mathrm{P}<0.05)$ was observed in the total biomass production over a cropping sequence between the two Sars in both 16 and $60 \mathrm{t} / \mathrm{ha}$ /crop-season FYM treatments. However, the harvest 
Table 1 Biomass (kg/ha; mean \pm standard deviation) and harvest index of crops during the six growing seasons under varied FYM input in Mullasar

\begin{tabular}{|c|c|c|c|c|c|c|c|}
\hline & $\begin{array}{l}\text { FYM treatments } \\
\text { (t/ha/crop- } \\
\text { season) }\end{array}$ & $\begin{array}{l}\text { April-October } \\
2003 \text { rice }\end{array}$ & $\begin{array}{l}\text { October 2003- } \\
\text { May } 2004 \\
\text { wheat }\end{array}$ & $\begin{array}{l}\text { June-October } \\
2004 \text { black- } \\
\text { gram }\end{array}$ & $\begin{array}{l}\text { October 2004- } \\
\text { April } 2005 \\
\text { fallow }\end{array}$ & $\begin{array}{l}\text { April-October } \\
2005 \text { rice }\end{array}$ & $\begin{array}{l}\text { October } 2005- \\
\text { May } 2006 \text { wheat }\end{array}$ \\
\hline \multirow[t]{4}{*}{ Root } & 0 & $1776 \pm 269$ & $1481 \pm 160$ & $94 \pm 5$ & - & $1768 \pm 58$ & $1525 \pm 267$ \\
\hline & 16 & $1838 \pm 125$ & $1944 \pm 278$ & $114 \pm 2$ & - & $1821 \pm 151$ & $1946 \pm 161$ \\
\hline & 30 & $2021 \pm 569$ & $1981 \pm 224$ & $123 \pm 6$ & - & $1950 \pm 113$ & $1872 \pm 22$ \\
\hline & 60 & $1820 \pm 115$ & $2128 \pm 165$ & $143 \pm 14$ & - & $2066 \pm 111$ & $2155 \pm 258$ \\
\hline \multirow[t]{4}{*}{ Shoot } & 0 & $2319 \pm 96$ & $2241 \pm 195$ & $434 \pm 7$ & - & $2376 \pm 140$ & $1930 \pm 158$ \\
\hline & 16 & $2318 \pm 208$ & $1907 \pm 128$ & $419 \pm 21$ & - & $2402 \pm 111$ & $2427 \pm 234$ \\
\hline & 30 & $2705 \pm 224$ & $2410 \pm 175$ & $482 \pm 5$ & - & $2704 \pm 77$ & $2592 \pm 288$ \\
\hline & 60 & $2803 \pm 230$ & $2740 \pm 140$ & $518 \pm 17$ & - & $3491 \pm 117$ & $2806 \pm 215$ \\
\hline \multirow[t]{4}{*}{ Grain } & 0 & $2065 \pm 389$ & $1018 \pm 160$ & $1808 \pm 52$ & - & $2151 \pm 45$ & $865 \pm 122$ \\
\hline & 16 & $2352 \pm 153$ & $1182 \pm 225$ & $1840 \pm 29$ & - & $2432 \pm 65$ & $932 \pm 77$ \\
\hline & 30 & $2602 \pm 252$ & $1481 \pm 160$ & $1894 \pm 59$ & - & $2547 \pm 344$ & $1636 \pm 144$ \\
\hline & 60 & $3361 \pm 237$ & $1759 \pm 424$ & $2094 \pm 49$ & - & $3079 \pm 116$ & $2555 \pm 198$ \\
\hline \multirow[t]{4}{*}{ Total Biomass } & 0 & $6160 \pm 444$ & $4740 \pm 195$ & $2335 \pm 54$ & - & $6295 \pm 187$ & $4321 \pm 309$ \\
\hline & 16 & $6508 \pm 287$ & $5033 \pm 440$ & $2373 \pm 13$ & - & $6655 \pm 86$ & $5304 \pm 298$ \\
\hline & 30 & $7328 \pm 479$ & $5873 \pm 362$ & $2500 \pm 57$ & - & $7201 \pm 412$ & $6099 \pm 446$ \\
\hline & 60 & $7984 \pm 51$ & $6626 \pm 665$ & $2755 \pm 73$ & - & $8636 \pm 110$ & $7516 \pm 559$ \\
\hline \multirow[t]{4}{*}{ HI } & 0 & $33.43 \pm 4.95$ & $21.59 \pm 4.13$ & $77.39 \pm 0.45$ & - & $34.19 \pm 1.08$ & $20.21 \pm 4.22$ \\
\hline & 16 & $36.19 \pm 2.89$ & $23.41 \pm 3.12$ & $77.55 \pm 0.91$ & - & $36.55 \pm 0.98$ & $17.65 \pm 2.38$ \\
\hline & 30 & $35.71 \pm 5.30$ & $25.28 \pm 2.96$ & $75.76 \pm 0.66$ & - & $35.27 \pm 2.82$ & $26.81 \pm 0.59$ \\
\hline & 60 & $42.10 \pm 3.13$ & $26.31 \pm 3.75$ & $76.01 \pm 0.62$ & - & $35.67 \pm 1.64$ & $34.04 \pm 2.38$ \\
\hline
\end{tabular}

Table 2 Biomass ( $\mathrm{kg} / \mathrm{ha}$; mean \pm standard deviation) and harvest index of crops during the six growing seasons under varied FYM input in Mallasar

\begin{tabular}{|c|c|c|c|c|c|c|c|}
\hline & $\begin{array}{l}\text { FYM treatments } \\
\text { (t/ha/crop- } \\
\text { season) }\end{array}$ & $\begin{array}{l}\text { June-October } \\
2003 \text { black- } \\
\text { gram }\end{array}$ & $\begin{array}{l}\text { October 2003- } \\
\text { April } 2004 \\
\text { fallow }\end{array}$ & $\begin{array}{l}\text { April-October } 2004 \\
\text { rice }\end{array}$ & $\begin{array}{l}\text { October 2004- } \\
\text { May } 2005 \\
\text { wheat }\end{array}$ & $\begin{array}{l}\text { Jnue-October } \\
2005 \text { black- } \\
\text { gram }\end{array}$ & $\begin{array}{l}\text { October 2005- } \\
\text { April } 2006 \\
\text { fallow }\end{array}$ \\
\hline \multirow[t]{4}{*}{ Root } & 0 & $98 \pm 4$ & - & $1735 \pm 83$ & $1659 \pm 202$ & $96 \pm 5$ & - \\
\hline & 16 & $138 \pm 43$ & - & $1848 \pm 257$ & $1882 \pm 172$ & $117 \pm 14$ & - \\
\hline & 30 & $116 \pm 6$ & - & $1919 \pm 142$ & $1952 \pm 84$ & $114 \pm 13$ & - \\
\hline & 60 & $134 \pm 0.2$ & - & $1961 \pm 149$ & $2056 \pm 195$ & $159 \pm 5$ & - \\
\hline \multirow[t]{4}{*}{ Shoot } & 0 & $404 \pm 15$ & - & $2325 \pm 87$ & $2055 \pm 266$ & $435 \pm 7$ & - \\
\hline & 16 & $421 \pm 5$ & - & $2538 \pm 145$ & $2331 \pm 213$ & $440 \pm 21$ & - \\
\hline & 30 & $479 \pm 10$ & - & $2597 \pm 114$ & $2359 \pm 171$ & $481 \pm 10$ & - \\
\hline & 60 & $526 \pm 17$ & - & $3574 \pm 473$ & $2856 \pm 282$ & $513 \pm 37$ & - \\
\hline \multirow[t]{4}{*}{ Grain } & 0 & $1789 \pm 58$ & - & $2175 \pm 223$ & $1078 \pm 151$ & $1776 \pm 55$ & - \\
\hline & 16 & $1822 \pm 29$ & - & $2333 \pm 15$ & $1169 \pm 103$ & $1822 \pm 71$ & - \\
\hline & 30 & $1940 \pm 21$ & - & $2475 \pm 288$ & $1693 \pm 212$ & $1941 \pm 27$ & - \\
\hline & 60 & $2091 \pm 62$ & - & $3100 \pm 164$ & $2425 \pm 52$ & $2084 \pm 76$ & - \\
\hline \multirow[t]{4}{*}{ Total Biomass } & 0 & $2291 \pm 72$ & - & $6235 \pm 360$ & $4792 \pm 216$ & $2307 \pm 54$ & - \\
\hline & 16 & $2381 \pm 27$ & - & $6720 \pm 334$ & $5382 \pm 486$ & $2379 \pm 78$ & - \\
\hline & 30 & $2535 \pm 32$ & - & $6990 \pm 366$ & $6003 \pm 20$ & $2536 \pm 24$ & - \\
\hline & 60 & $2751 \pm 76$ & - & $8635 \pm 561$ & $7337 \pm 91$ & $2756 \pm 59$ & - \\
\hline \multirow[t]{4}{*}{ HI } & 0 & $78.09 \pm 0.11$ & - & $34.83 \pm 1.73$ & $22.62 \pm 4.21$ & $76.98 \pm 0.67$ & - \\
\hline & 16 & $76.54 \pm 1.62$ & - & $34.78 \pm 1.71$ & $21.72 \pm 0.28$ & $76.58 \pm 0.51$ & - \\
\hline & 30 & $76.53 \pm 0.31$ & - & $35.34 \pm 2.70$ & $28.20 \pm 3.54$ & $76.53 \pm 0.34$ & - \\
\hline & 60 & $76.01 \pm 0.33$ & - & $35.95 \pm 1.75$ & $33.05 \pm 0.68$ & $75.59 \pm 1.41$ & - \\
\hline
\end{tabular}



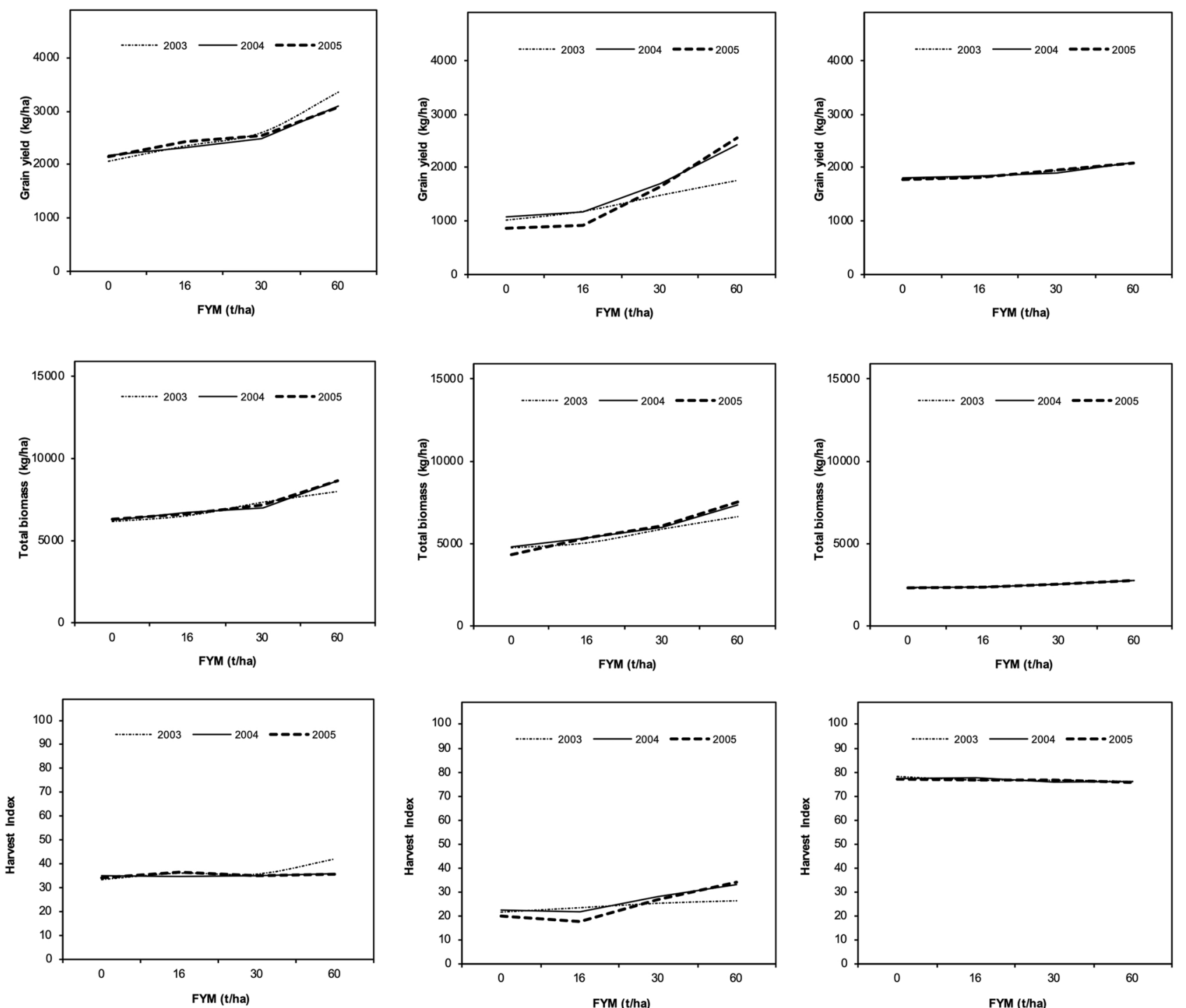

Fig. 4 Grain yield, total biomass and harvest index under various treatments of FYM

indices were not significantly $(\mathrm{P}>0.05)$ different for crop sequences under $16 \mathrm{t} / \mathrm{ha} / \mathrm{crop}$-season FYM treatment.

Variation in economic yields of component crops and economic rice equivalent yield of crop sequences during years is shown in Table 3. The coefficient of variation of economic yield in different years was greater for wheat as compared to rice and black gram. The percentage increase in mean economic yield for varied doses of FYM over no input treatment showed that wheat had positive effect of FYM; yields in the 16t/ha FYM treatment were 17\%, 30 t/ha FYM $72 \%$ and $140 \%$ in 60 t/ha FYM treatment higher than the control (no FYM input). Results for rice, wheat and blackgram for economic rice equivalent yield (Table 4$)$ indicate that while yields were significantly different $(\mathrm{P}<0.05)$ in different FYM treatments but not in different years. On the other hand, the economic rice equivalent yield of cropping sequence showed significant differences $(\mathrm{P}<0.05)$ between FYM treatments as well as years. Protein level increased in all crops with increase in FYM input rate (Table 5). This trend was most conspicuous in wheat followed by rice and blackgram.

Soil organic carbon, total nitrogen, sodium, calcium, magnesium and available phosphorus levels in the soil generally showed direct positive relationship with the FYM input rates (Tables 6,7 ). Thus, the highest levels of these elements were recorded in $60 \mathrm{t} / \mathrm{ha} /$ crop-season FYM treatment and lowest in control (no FYM input).

During the three year study the amount of total nitrogen in the soil pool decreased after first kharif (rice) and rabi (wheat) cropping but increased after second kharif (black gram) and second rabi (fallow) in control (no FYM input), did not show any major changes in 16 and 30 t/ha/ 


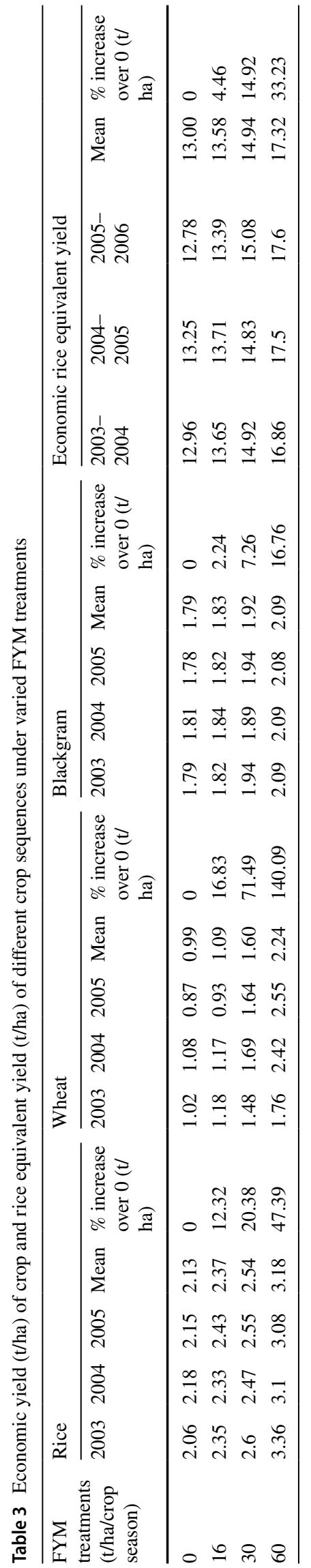

crop-season FYM treatment and increased continuously under $60 \mathrm{t} / \mathrm{ha}$ /crop-season FYM treatment in both Mullasar and Malasar (Tables 6, 7). Soil pH decreased with cropping length and increased during legume cropping and fallow phases (Tables 6,7). The changes in soil $\mathrm{pH}$ were more pronounced in control (no FYM input) and $16 \mathrm{t} / \mathrm{ha} /$ crop-season FYM treatments as compared to 30 and $60 \mathrm{t} / \mathrm{ha} / \mathrm{crop}$-season FYM treatments. As a general trend during the three years of study, soil $\mathrm{pH}$ decreased (becoming more acidic) as with passage of time. Soil organic carbon generally declined up to second kharif season and then showed improvement during second rabi (fallow) under no input FYM treatment and 16 t/ha/crop-season FYM treatment. However, plots receiving FYM 30 and 60 t/ha/crop-season generally showed a gradual buildup of soil organic carbon, though there was a transient depletion phase during rice crop phase (Tables 6, 7). Total $\mathrm{N}, \mathrm{Mg}$ and available $\mathrm{P}$ showed temporal patterns similar to soil organic carbon. Total $\mathrm{Ca}, \mathrm{Na}$ and $\mathrm{K}$ showed quite different patterns (Tables 6,7).

Net changes $C$, total $N, K$ and available $P$ are given in Table 8. While the soils of fields exposed to 0 and $16 \mathrm{t} / \mathrm{ha} /$ crop-season FYM treatments showed a net decrease, those exposed to 30 and $60 \mathrm{t} / \mathrm{ha} / \mathrm{crop}$-season FYM treatments showed a net increase in the levels of these elements.

\section{Discussion}

Agriculture productivity depends on various inputs and environmental conditions, specifically soil type, rainfall and temperature. To achieve the goal of higher agricultural production, optimal dozes and combinations of inputs are necessary. Inputs can be (1) conventional such as land, labour, capital and irrigation; (2) biophysical/chemical such as FYM, fertilizers and pesticides; (3) biological such as seeds and other genetic resources; and (4) environmental such as soil, rainfall and temperature. Several workers have concluded organic and inorganic fertilizers and crop varieties as the most crucial inputs determining crop yields across varied soil types and climate regimes (Gupta et al. 2003; Meertens et al. 2003; Kiani et al. 2005; Shah and Ahmad 2006; Shrestha et al. 2006; Mushtaqe et al. 2007; Singh et al. 2007; Zingore et al. 2007; Han et al. 2016; Dinakaran et al. 2019).

FYM input rates in traditional farming enormously vary (Table 9). This variation may be related to quality of FYM, type of cropping systems and soil conditions. The farmers in the study area generally applied about 30-35 t FYM/ha during kharif rice cropping, 16-25 t FYM/ha during rabi wheat cropping and 8-12 t FYM/ha during kharif millet cropping. FYM is not applied for growing legumes, while millets mixed with legumes generally received lower dozes ( 6-8 t FYM/ha). Participation in designing, implementing 
Table 4 ANOVA results for rice, wheat, blackgram and rice equivalent yields

\begin{tabular}{llll}
\hline & Years & FYM treatments & Year vs. FYM treatments \\
\hline Rice & $\mathrm{NS}(\mathrm{F}=0.336 ; P=0.718)$ & $\mathrm{S}(\mathrm{F}=36.734 ; P=0.000004)$ & $\mathrm{NS}(\mathrm{F}=0.595 ; P=0.732)$ \\
Wheat & $\mathrm{NS}(\mathrm{F}=4.384 ; P=0.024)$ & $\mathrm{S}(\mathrm{F}=80.645 ; P=0.000001)$ & $\mathrm{S}(\mathrm{F}=4.658 ; P=0.003)$ \\
Blackgram & $\mathrm{NS}(\mathrm{F}=0.025 ; P=0.975)$ & $\mathrm{S}(\mathrm{F}=59.148 ; P=0.000003)$ & $\mathrm{NS}(\mathrm{F}=0.403 ; P=0.870)$ \\
Rice equivalent yields & $\mathrm{NS}(\mathrm{F}=0.857 ; P=0.437)$ & $\mathrm{S}(\mathrm{F}=186.258 ; P=0.0000001)$ & $\mathrm{NS}(\mathrm{F}=1.185 ; P=0.347)$ \\
\hline
\end{tabular}

$N S$ not significant, $S$ significant

Table 5 Protein production $(\mathrm{kg} / \mathrm{ha})$ under various FYM treatments

\begin{tabular}{|c|c|c|c|c|c|c|c|c|c|c|c|c|}
\hline \multirow{2}{*}{$\begin{array}{l}\text { FYM treatments (t/ } \\
\text { ha/crop season) }\end{array}$} & \multicolumn{4}{|l|}{ Rice } & \multicolumn{4}{|l|}{ Wheat } & \multicolumn{4}{|c|}{ Blackgram } \\
\hline & 2003 & 2004 & 2005 & Mean & 2003 & 2004 & 2005 & Mean & 2003 & 2004 & 2005 & Mean \\
\hline 0 & 125.37 & 132.08 & 130.63 & 129.36 & 110.56 & 117.06 & 93.95 & 107.19 & 429.30 & 433.81 & 426.32 & 429.81 \\
\hline 16 & 142.80 & 141.66 & 147.69 & 144.05 & 128.27 & 126.86 & 101.15 & 118.76 & 437.33 & 441.68 & 437.36 & 438.79 \\
\hline 30 & 157.98 & 150.27 & 154.66 & 154.30 & 160.82 & 183.76 & 177.62 & 174.07 & 465.60 & 454.52 & 465.89 & 462.00 \\
\hline 60 & 204.08 & 188.22 & 186.97 & 193.09 & 190.92 & 263.25 & 277.36 & 243.84 & 501.90 & 502.62 & 500.12 & 501.55 \\
\hline
\end{tabular}

and monitoring led local farmers to realize scope of raising crop yields as well as soil quality by increasing FYM input. The present study shows that if the farmers can maintain application of $30 \mathrm{t} / \mathrm{ha}$ of FYM during rice and wheat phase of cropping, rise in yields as well as soil organic carbon pools could be maintained in a healthy status and the use of long fallow helps them in achieving the yield stability. Shrestha et al. (2006) reported that rice-wheat system receiving about $10 \mathrm{t} \mathrm{FYM} / \mathrm{ha} /$ year and $157 \mathrm{~kg}$ inorganic fertilizer/ha/year in warm temperate conditions accumulated higher soil $\mathrm{C}$ as compared to subtropical rice-wheat system receiving only $5 \mathrm{t} \mathrm{FYM/ha/year} \mathrm{and} \mathrm{comparable} \mathrm{inorganic}$ fertilizer input in Nepal. Similar trends are reflected from many other studies (Kaini et al. 2005; Kundu et al. 2007a, b; Hartmann et al. 2015; Abe et al. 2016; Luo et al. 2016; Dinakaran et al. 2019).

Many researchers have attributed scarcity to sub-optimal dozes of FYM (Yadav et al. 1998; Ladha et al. 2003; Singh et al. 2004; Kundu et al. 2007a). Such reductions in FYM applications could lead to reduction in economic as well as biological yields. The results of the present study confirm the pattern observed by Shah and Ahmad (2006) in Azad Kashmir, Gupta et al. (2003) in Indo-Gangetic Plains and Shrestha et al. (2006) in Nepal. Production efficiency of cropping systems differing in crop sequences can be compared in terms of economic yield equivalents of major crops. The present study showed that the winter season crop (wheat) was most responsive to FYM input in all years. Similar trends were also reported by Shah and Ahmad (2006). Another indicator could be protein production from the cropping systems. Grain protein levels increased significantly with increase in rate of FYM for all crops. However, the quantity of grain protein varied between the years. Such variations were also reported by Singh et al. (2002).

Huge amounts of nutrients are mined from soil in the form of food and feed products taken out of crop fields. Application of FYM and leaving the field as fallow are two major strategies used by the farmers to improve soil nutrient status in almost all systems of organic agriculture, with FYM input rates varying depending on socio-ecological conditions (Table 9). The soil nutrient status (i.e. elemental concentrations) reduced significantly during the three year study period when the soils received FYM @ 16 t/ha/cropseason and increased in treatments receiving FYM @ 30 or $60 \mathrm{t} / \mathrm{ha}$ /crop-season. This study thus indicates that the farmers realize a need of increasing FYM input in cereals but are unable to satisfy this need because of scarcity of labor rather than of biomass needed to produce FYM application during blackgram cropping did not provide any significant additional economic or biological yield benefits. Farmer's practices of growing legumes on residual soil fertility and of millet-legume mixed crops with quite low FYM inputs are thus scientifically sound. Apart from incorporation of FYM, inclusion of legumes, which fix nitrogen and whose shoots do not have any direct economic uses and hence left out in the field in the crop sequences is one major strategy adapted by farmers to maintain soil fertility and achieve land and labor productivity in rainfed slopes at par with wet rice monoculture in valley lands (Chandra 2007). The benefits of legumes in rotation are not solely due to biological fixation of nitrogen but also due to improved soil structure, reduced disease incidence and increased mycorrhizal colonization (Wani et al. 1995; Singh et al. 2002, 2007; Zingore et al. 2007). 
Table 6 Changes in concentration $(\mathrm{mg} / 100 \mathrm{~g}$ ) of elements in soil during 3 years cropping in Mullasar

\begin{tabular}{|c|c|c|c|c|c|c|c|c|}
\hline & $\begin{array}{l}\text { FYM treat- } \\
\text { ments (t/ha/ } \\
\text { crop-season) }\end{array}$ & $\begin{array}{l}\text { October } \\
\text { 2002-April } \\
2003 \text { fallow }\end{array}$ & $\begin{array}{l}\text { April-October } \\
2003 \text { rice }\end{array}$ & $\begin{array}{l}\text { October 2003- } \\
\text { May } 2004 \\
\text { wheat }\end{array}$ & $\begin{array}{l}\text { June-October } \\
2004 \text { blackgram }\end{array}$ & $\begin{array}{l}\text { October 2004- } \\
\text { April } 2005 \\
\text { fallow }\end{array}$ & $\begin{array}{l}\text { April-October } \\
2005 \text { rice }\end{array}$ & $\begin{array}{l}\text { October 2005- } \\
\text { May } 2006 \\
\text { wheat }\end{array}$ \\
\hline \multirow[t]{4}{*}{$\mathrm{C}$} & 0 & $1.585 \pm 0.021^{\mathrm{a}}$ & $1.441 \pm 0.0416^{\mathrm{c}}$ & $1.357 \pm 0.036^{\mathrm{a}}$ & $1.297 \pm 0.042^{\mathrm{cb}}$ & $1.439 \pm 0.055^{\mathrm{d}}$ & $1.345 \pm 0.021^{\mathrm{d}}$ & $1.295 \pm 0.021^{\mathrm{c}}$ \\
\hline & 16 & $1.585 \pm 0.021^{\mathrm{a}}$ & $1.513 \pm 0.0208^{b c}$ & $1.597 \pm 0.021^{\mathrm{c}}$ & $1.549 \pm 0.042^{\mathrm{b}}$ & $1.583 \pm 0.042^{\mathrm{c}}$ & $1.477 \pm 0.042^{\mathrm{cd}}$ & $1.499 \pm 0.042^{\mathrm{b}}$ \\
\hline & 30 & $1.585 \pm 0.021^{\mathrm{a}}$ & $1.585 \pm 0.0208^{\mathrm{ab}}$ & $1.837 \pm 0.055^{\mathrm{b}}$ & $2.053 \pm 0.021^{\mathrm{a}}$ & $2.087 \pm 0.021^{\mathrm{b}}$ & $1.849 \pm 0.021^{\mathrm{b}}$ & $1.883 \pm 0.036^{\mathrm{b}}$ \\
\hline & 60 & $1.585 \pm 0.021^{\mathrm{a}}$ & $1.681 \pm 0.0360^{\mathrm{a}}$ & $1.993 \pm 0.083^{\mathrm{a}}$ & $2.161 \pm 0.021^{\mathrm{a}}$ & $2.183 \pm 0.055^{\mathrm{a}}$ & $1.981 \pm 0.042^{\mathrm{ac}}$ & $2.111 \pm 0.042^{c}$ \\
\hline \multirow[t]{4}{*}{$\mathrm{N}$} & 0 & $0.123 \pm 0.006^{\mathrm{a}}$ & $0.105 \pm 0.006^{\mathrm{b}}$ & $0.097 \pm 0.009^{c}$ & $0.115 \pm 0.003^{b}$ & $0.111 \pm 0.009^{b}$ & $0.107 \pm 0.009^{c}$ & $0.103 \pm 0.007^{\mathrm{b}}$ \\
\hline & 16 & $0.123 \pm 0.006^{\mathrm{a}}$ & $0.121 \pm 0.009^{b}$ & $0.123 \pm 0.006^{\mathrm{b}}$ & $0.123 \pm 0.007^{\mathrm{b}}$ & $0.119 \pm 0.012^{\mathrm{ab}}$ & $0.117 \pm 0.009^{b c}$ & $0.115 \pm 0.003^{b}$ \\
\hline & 30 & $0.123 \pm 0.006^{\mathrm{a}}$ & $0.123 \pm 0.006^{\mathrm{b}}$ & $0.125 \pm 0.009^{b c}$ & $0.129 \pm 0.009^{b}$ & $0.121 \pm 0.015^{\mathrm{ab}}$ & $0.125 \pm 0.012^{\mathrm{b}}$ & $0.123 \pm 0.009^{b}$ \\
\hline & 60 & $0.123 \pm 0.006^{\mathrm{a}}$ & $0.147 \pm 0.00^{\mathrm{a}}$ & $0.167 \pm 0.003^{\mathrm{a}}$ & $0.170 \pm 0.007^{\mathrm{a}}$ & $0.147 \pm 0.009^{\mathrm{a}}$ & $0.162 \pm 0.006^{\mathrm{a}}$ & $0.164 \pm 0.007^{\mathrm{a}}$ \\
\hline \multirow[t]{4}{*}{$\mathrm{P}$} & 0 & $0.043 \pm 0.002^{\mathrm{a}}$ & $0.040 \pm 0.001^{\mathrm{b}}$ & $0.039 \pm 0.002^{\mathrm{b}}$ & $0.040 \pm 0.002^{\mathrm{b}}$ & $0.037 \pm 0.001^{b}$ & $0.040 \pm 0.003^{\mathrm{a}}$ & $0.036 \pm 0.002^{b}$ \\
\hline & 16 & $0.043 \pm 0.002^{\mathrm{a}}$ & $0.046 \pm 0.001^{\mathrm{a}}$ & $0.041 \pm 0.0002^{\mathrm{b}}$ & $0.042 \pm 0.002^{\mathrm{ab}}$ & $0.045 \pm 0.006^{\mathrm{b}}$ & $0.041 \pm 0.006^{\mathrm{a}}$ & $0.043 \pm 0.003^{\mathrm{ab}}$ \\
\hline & 30 & $0.043 \pm 0.002^{\mathrm{a}}$ & $0.051 \pm 0.001^{\mathrm{a}}$ & $0.044 \pm 0.004^{\mathrm{ab}}$ & $0.047 \pm 0.003^{\mathrm{ab}}$ & $0.050 \pm 0.002^{\mathrm{ab}}$ & $0.043 \pm 0.001^{\mathrm{a}}$ & $0.048 \pm 0.001^{\mathrm{a}}$ \\
\hline & 60 & $0.043 \pm 0.002^{\mathrm{a}}$ & $0.051 \pm 0.003^{\mathrm{ab}}$ & $0.049 \pm 0.002^{\mathrm{a}}$ & $0.045 \pm 0.006^{\mathrm{a}}$ & $0.049 \pm 0.001^{\mathrm{a}}$ & $0.046 \pm 0.005^{\mathrm{a}}$ & $0.050 \pm 0.002^{\mathrm{a}}$ \\
\hline \multirow[t]{4}{*}{ K } & 0 & $0.104 \pm 0.002^{\mathrm{a}}$ & $0.098 \pm 0.003^{b}$ & $0.089 \pm 0.009^{c}$ & $0.078 \pm 0.001^{b}$ & $0.071 \pm 0.002^{\mathrm{b}}$ & $0.071 \pm 0.002^{\mathrm{b}}$ & $0.077 \pm 0.004^{b}$ \\
\hline & 16 & $0.104 \pm 0.002^{\mathrm{a}}$ & $0.104 \pm 0.004^{b}$ & $0.092 \pm 0.005^{\mathrm{bc}}$ & $0.080 \pm 0.004^{\mathrm{ab}}$ & $0.073 \pm 0.004^{\mathrm{ab}}$ & $0.106 \pm 0.005^{\mathrm{a}}$ & $0.080 \pm 0.002^{\mathrm{b}}$ \\
\hline & 30 & $0.104 \pm 0.002^{\mathrm{a}}$ & $0.114 \pm 0.003^{\mathrm{a}}$ & $0.114 \pm 0.003^{\mathrm{a}}$ & $0.082 \pm 0.002^{\mathrm{ab}}$ & $0.086 \pm 0.003^{\mathrm{a}}$ & $0.111 \pm 0.001^{\mathrm{a}}$ & $0.111 \pm 0.002^{\mathrm{a}}$ \\
\hline & 60 & $0.104 \pm 0.002^{\mathrm{a}}$ & $0.126 \pm 0.004^{\mathrm{a}}$ & $0.114 \pm 0.003^{\mathrm{ab}}$ & $0.089 \pm 0.004^{\mathrm{a}}$ & $0.081 \pm 0.010^{\mathrm{ab}}$ & $0.114 \pm 0.004^{\mathrm{a}}$ & $0.110 \pm 0.001^{\mathrm{a}}$ \\
\hline \multirow[t]{4}{*}{$\mathrm{Na}$} & 0 & $0.074 \pm 0.009^{\mathrm{a}}$ & $0.061 \pm 0.003^{\mathrm{a}}$ & $0.060 \pm 0.005^{\mathrm{b}}$ & $0.064 \pm 0.005^{\mathrm{a}}$ & $0.064 \pm 0.001^{\mathrm{b}}$ & $0.056 \pm 0.004^{\mathrm{ab}}$ & $0.058 \pm 0.006^{\mathrm{ab}}$ \\
\hline & 16 & $0.074 \pm 0.009^{\mathrm{a}}$ & $0.068 \pm 0.004^{\mathrm{a}}$ & $0.064 \pm 0.004^{\mathrm{a}}$ & $0.065 \pm 0.004^{\mathrm{a}}$ & $0.065 \pm 0.002^{\mathrm{ab}}$ & $0.055 \pm 0.001^{\mathrm{b}}$ & $0.058 \pm 0.004^{b}$ \\
\hline & 30 & $0.074 \pm 0.009^{\mathrm{a}}$ & $0.070 \pm 0.007^{\mathrm{a}}$ & $0.064 \pm 0.001^{\mathrm{ab}}$ & $0.064 \pm 0.001^{\mathrm{a}}$ & $0.068 \pm 0.004^{\mathrm{ab}}$ & $0.066 \pm 0.002^{\mathrm{a}}$ & $0.062 \pm 0.004^{\mathrm{a}}$ \\
\hline & 60 & $0.074 \pm 0.009^{\mathrm{a}}$ & $0.065 \pm 0.003^{\mathrm{a}}$ & $0.065 \pm 0.001^{\mathrm{ab}}$ & $0.068 \pm 0.003^{\mathrm{a}}$ & $0.069 \pm 0.002^{\mathrm{a}}$ & $0.066 \pm 0.002^{\mathrm{a}}$ & $0.063 \pm 0.002^{\mathrm{ab}}$ \\
\hline \multirow[t]{4}{*}{$\mathrm{Ca}$} & 0 & $0.090 \pm 0.001^{\mathrm{a}}$ & $0.075 \pm 0.001^{\mathrm{c}}$ & $0.072 \pm 0.002^{c}$ & $0.071 \pm 0.001^{\mathrm{c}}$ & $0.070 \pm 0.003^{b}$ & $0.074 \pm 0.001^{\mathrm{b}}$ & $0.074 \pm 0.002^{c}$ \\
\hline & 16 & $0.090 \pm 0.001^{\mathrm{a}}$ & $0.086 \pm 0.001^{b}$ & $0.084 \pm 0.001^{\mathrm{b}}$ & $0.076 \pm 0.002^{b}$ & $0.072 \pm 0.002^{b}$ & $0.085 \pm 0.004^{\mathrm{b}}$ & $0.085 \pm 0.001^{b}$ \\
\hline & 30 & $0.090 \pm 0.001^{\mathrm{a}}$ & $0.089 \pm 0.001^{\mathrm{a}}$ & $0.085 \pm 0.003^{\mathrm{ab}}$ & $0.096 \pm 0.004^{\mathrm{a}}$ & $0.084 \pm 0.001^{\mathrm{a}}$ & $0.097 \pm 0.012^{\mathrm{ab}}$ & $0.085 \pm 0.003^{b}$ \\
\hline & 60 & $0.090 \pm 0.001^{\mathrm{a}}$ & $0.092 \pm 0.002^{\mathrm{a}}$ & $0.096 \pm 0.002^{\mathrm{a}}$ & $0.113 \pm 0.012^{\mathrm{a}}$ & $0.088 \pm 0.003^{\mathrm{a}}$ & $0.117 \pm 0.006^{\mathrm{a}}$ & $0.104 \pm 0.005^{\mathrm{a}}$ \\
\hline \multirow[t]{4}{*}{$\mathrm{Mg}$} & 0 & $0.093 \pm 0.003^{\mathrm{a}}$ & $0.085 \pm 0.005^{\mathrm{b}}$ & $0.076 \pm 0.003^{c}$ & $0.083 \pm 0.002^{\mathrm{c}}$ & $0.081 \pm 0.007^{\mathrm{d}}$ & $0.085 \pm 0.001^{\mathrm{c}}$ & $0.086 \pm 0.002^{c}$ \\
\hline & 16 & $0.093 \pm 0.003^{\mathrm{a}}$ & $0.086 \pm 0.007^{\mathrm{ab}}$ & $0.081 \pm 0.003^{b c}$ & $0.096 \pm 0.006^{\mathrm{bc}}$ & $0.121 \pm 0.004^{c}$ & $0.133 \pm 0.010^{\mathrm{b}}$ & $0.130 \pm 0.002^{\mathrm{b}}$ \\
\hline & 30 & $0.093 \pm 0.003^{\mathrm{a}}$ & $0.093 \pm 0.004^{\mathrm{ab}}$ & $0.086 \pm 0.006^{\mathrm{b}}$ & $0.114 \pm 0.005^{\mathrm{ab}}$ & $0.119 \pm 0.006^{b c}$ & $0.136 \pm 0.006^{\mathrm{b}}$ & $0.129 \pm 0.004^{\mathrm{b}}$ \\
\hline & 60 & $0.093 \pm 0.003^{\mathrm{a}}$ & $0.109 \pm 0.005^{\mathrm{a}}$ & $0.104 \pm 0.001^{\mathrm{a}}$ & $0.123 \pm 0.002^{\mathrm{a}}$ & $0.180 \pm 0.005^{\mathrm{a}}$ & $0.158 \pm 0.003^{\mathrm{a}}$ & $0.163 \pm 0.006^{\mathrm{a}}$ \\
\hline
\end{tabular}

Concentrations of an element in different FYM treatments are significantly different $(\mathrm{P}<0.05)$ at a given sampling time if they are followed by different alphabet

With prohibition on expansion of agricultural land use with enforcement of Forest Conservation Act 1980 and increasing population within Himalaya as well as Indo-Gangetic plains dependent on ecosystem services flowing from it, sustainable agricultural land use intensification assumes importance for local food, nutritional and income security (Laishram et al. 2009, 2020). This study shows that increase in FYM input accompanies not only increase in productivity and profitability but substantial increase in carbon stocks serving the global community in terms of climate change mitigation. With availability of $>5$ ha of forest land per ha of agricultural land and prohibition on logging since 1970s, leaf litter removal, pruning of fodder trees and harvesting of grasses for hay from forests to generate FYM needed for incorporation
@ $60 \mathrm{t} / \mathrm{ha} / \mathrm{crop}$-season or so is likely to improve forest health by reducing dominance/favoring diversity together with improving agricultural productivity and climate change mitigation potential of agricultural land. There is a need of rewarding contribution of organic farms to carbon sequestration which is at present confined to forests. In situations where high quality forest leaf litter is not available, incentives for use of vermin-compost in place of traditional farm yard manure would be a feasible option (Rao et al. 2016; Saxena and Rao 2016). The present experiment was carried out in poor quality agricultural land and hence optimal dozes of farm yard manure is likely to be far below the highest input treatment of $60 \mathrm{t}$ of FYM input/ha after a decade or so based which needs to evaluated through long-term trials and mathematical models. 
Table 7 Changes in concentration $(\mathrm{mg} / 100 \mathrm{~g})$ of elements in soil during 3 years of cropping in Mallasar

\begin{tabular}{|c|c|c|c|c|c|c|c|c|}
\hline & $\begin{array}{l}\text { FYM treat- } \\
\text { ments (t/ha/ } \\
\text { crop-season) }\end{array}$ & $\begin{array}{l}\text { October } \\
\text { 2002-May } \\
2003 \text { wheat }\end{array}$ & $\begin{array}{l}\text { Jnue-October } \\
2003 \text { blackgram }\end{array}$ & $\begin{array}{l}\text { October 2003- } \\
\text { April } 2004 \\
\text { fallow }\end{array}$ & $\begin{array}{l}\text { April-October } \\
2004 \text { rice }\end{array}$ & $\begin{array}{l}\text { October 2004- } \\
\text { May } 2005 \\
\text { wheat }\end{array}$ & $\begin{array}{l}\text { June-October } \\
2005 \text { black- } \\
\text { gram }\end{array}$ & $\begin{array}{l}\text { October 2005- } \\
\text { April } 2006 \\
\text { fallow }\end{array}$ \\
\hline \multirow[t]{4}{*}{$\mathrm{C}$} & 0 & $859 \pm 0.042^{\mathrm{a}}$ & $1.523 \pm 0.036^{\mathrm{b}}$ & $1.585 \pm 0.055^{\mathrm{ab}}$ & $1.355 \pm 0.042^{\mathrm{c}}$ & $1.307 \pm 0.157^{c}$ & $1.296 \pm 0.062^{\mathrm{c}}$ & $1.356 \pm 0.021^{\mathrm{c}}$ \\
\hline & 16 & $859 \pm 0.042^{\mathrm{a}}$ & $1.607 \pm 0.021^{\mathrm{ab}}$ & $1.897 \pm 0.036^{\mathrm{b}}$ & $1.583 \pm 0.021^{\mathrm{bd}}$ & $1.595 \pm 0.036^{\mathrm{bc}}$ & $1.620 \pm 0.036^{\mathrm{b}}$ & $1.680 \pm 0.075^{\mathrm{c}}$ \\
\hline & 30 & $.859 \pm 0.042^{\mathrm{a}}$ & $1.703 \pm 0.036^{\mathrm{ab}}$ & $1.993 \pm 0.075^{\mathrm{ab}}$ & $1.679 \pm 0.042^{\mathrm{a}}$ & $1.679 \pm 0.042^{\mathrm{b}}$ & $1.692 \pm 0.062^{\mathrm{b}}$ & $2.076 \pm 0.055^{\mathrm{b}}$ \\
\hline & 60 & $859 \pm 0.042^{\mathrm{a}}$ & $1.787 \pm 0.021^{\mathrm{a}}$ & $2.041 \pm 0.072^{\mathrm{a}}$ & $1.715 \pm 0.042^{\mathrm{ad}}$ & $1.811 \pm 0.095^{\mathrm{a}}$ & $2.040 \pm 0.091^{\mathrm{a}}$ & $2.052 \pm 0.036^{\mathrm{a}}$ \\
\hline \multirow[t]{4}{*}{$\mathrm{N}$} & 0 & $.131 \pm 0.007^{\mathrm{a}}$ & $0.143 \pm 0.003^{\mathrm{d}}$ & $0.129 \pm 0.006^{\mathrm{b}}$ & $0.101 \pm 0.006^{\mathrm{a}}$ & $0.089 \pm 0.012^{\mathrm{c}}$ & $0.117 \pm 0.009^{c}$ & $0.117 \pm 0.003^{c}$ \\
\hline & 16 & $0.131 \pm 0.007^{\mathrm{a}}$ & $0.149 \pm 0.003^{c}$ & $0.131 \pm 0.003^{c}$ & $0.123 \pm 0.009^{b}$ & $0.123 \pm 0.007^{b}$ & $0.131 \pm 0.007^{b}$ & $0.127 \pm 0.009^{b}$ \\
\hline & 30 & $0.131 \pm 0.007^{\mathrm{a}}$ & $0.155 \pm 0.004^{\text {bd }}$ & $0.143 \pm 0.009^{\mathrm{ac}}$ & $0.137 \pm 0.006^{\mathrm{a}}$ & $0.143 \pm 0.006^{\mathrm{a}}$ & $0.152 \pm 0.003^{b}$ & $0.147 \pm 0.009^{\mathrm{a}}$ \\
\hline & 60 & $0.131 \pm 0.007^{\mathrm{a}}$ & $0.167 \pm 0.003^{\mathrm{ac}}$ & $0.165 \pm 0.010^{\mathrm{a}}$ & $0.162 \pm 0.012^{\mathrm{a}}$ & $0.168 \pm 0.007^{\mathrm{ac}}$ & $0.192 \pm 0.006^{\mathrm{a}}$ & $0.166 \pm 0.006^{\mathrm{a}}$ \\
\hline \multirow[t]{4}{*}{$\mathrm{P}$} & 0 & $0.041 \pm 0.006^{\mathrm{a}}$ & $0.040 \pm 0.002^{\mathrm{a}}$ & $0.038 \pm 0.003^{\mathrm{b}}$ & $0.042 \pm 0.008^{\mathrm{a}}$ & $0.039 \pm 0.004^{\mathrm{a}}$ & $0.039 \pm 0.004^{\mathrm{a}}$ & $0.040 \pm 0.002^{\mathrm{b}}$ \\
\hline & 16 & $0.041 \pm 0.006^{\mathrm{a}}$ & $0.041 \pm 0.002^{\mathrm{a}}$ & $0.037 \pm 0.0004^{\mathrm{b}}$ & $0.044 \pm 0.006^{\mathrm{a}}$ & $0.044 \pm 0.002^{\mathrm{a}}$ & $0.039 \pm 0.006^{\mathrm{a}}$ & $0.045 \pm 0.002^{\mathrm{ab}}$ \\
\hline & 30 & $0.041 \pm 0.006^{\mathrm{a}}$ & $0.044 \pm 0.002^{\mathrm{a}}$ & $0.045 \pm 0.001^{\mathrm{a}}$ & $0.046 \pm 0.002^{\mathrm{a}}$ & $0.044 \pm 0.002^{\mathrm{a}}$ & $0.045 \pm 0.002^{\mathrm{a}}$ & $0.049 \pm 0.001^{\mathrm{a}}$ \\
\hline & 60 & $.041 \pm 0.006^{\mathrm{a}}$ & $0.043 \pm 0.003^{\mathrm{a}}$ & $0.043 \pm 0.009^{\mathrm{ab}}$ & $0.050 \pm 0.006^{\mathrm{a}}$ & $0.044 \pm 0.002^{\mathrm{a}}$ & $0.048 \pm 0.004^{\mathrm{a}}$ & $0.052 \pm 0.001^{\mathrm{a}}$ \\
\hline \multirow[t]{4}{*}{ K } & 0 & $0.115 \pm 0.003^{\mathrm{a}}$ & $0.109 \pm 0.002^{\mathrm{b}}$ & $0.101 \pm 0.003^{\mathrm{b}}$ & $0.093 \pm 0.003^{c}$ & $0.093 \pm 0.001^{b}$ & $0.086 \pm 0.007^{\mathrm{a}}$ & $0.110 \pm 0.004^{\mathrm{a}}$ \\
\hline & 16 & $0.115 \pm 0.003^{\mathrm{a}}$ & $0.112 \pm 0.002^{\mathrm{a}}$ & $0.113 \pm 0.003^{\mathrm{a}}$ & $0.107 \pm 0.004^{b}$ & $0.106 \pm 0.003^{c}$ & $0.113 \pm 0.004^{\mathrm{a}}$ & $0.104 \pm 0.009^{\mathrm{a}}$ \\
\hline & 30 & $0.115 \pm 0.003^{\mathrm{a}}$ & $0.111 \pm 0.002^{\mathrm{ab}}$ & $0.110 \pm 0.002^{\mathrm{a}}$ & $0.107 \pm 0.007^{\mathrm{abc}}$ & $0.107 \pm 0.003^{\mathrm{ac}}$ & $0.108 \pm 0.010^{\mathrm{a}}$ & $0.115 \pm 0.003^{\mathrm{a}}$ \\
\hline & 60 & $0.115 \pm 0.003^{\mathrm{a}}$ & $0.113 \pm 0.002^{\mathrm{a}}$ & $0.111 \pm 0.001^{\mathrm{a}}$ & $0.112 \pm 0.004^{\mathrm{a}}$ & $0.112 \pm 0.002^{\mathrm{a}}$ & $0.111 \pm 0.006^{\mathrm{a}}$ & $0.118 \pm 0.600^{\mathrm{a}}$ \\
\hline \multirow[t]{4}{*}{$\mathrm{Na}$} & 0 & $0.063 \pm 0.004^{\mathrm{a}}$ & $0.064 \pm 0.004^{\mathrm{a}}$ & $0.063 \pm 0.005^{\mathrm{bc}}$ & $0.066 \pm 0.003^{\mathrm{a}}$ & $0.066 \pm 0.008^{\mathrm{bc}}$ & $0.064 \pm 0.004^{\mathrm{a}}$ & $0.065 \pm 0.016^{\mathrm{acd}}$ \\
\hline & 16 & $0.063 \pm 0.004^{\mathrm{a}}$ & $0.062 \pm 0.005^{\mathrm{a}}$ & $0.074 \pm 0.003^{\mathrm{bd}}$ & $0.073 \pm 0.004^{\mathrm{a}}$ & $0.074 \pm 0.001^{\mathrm{b}}$ & $0.076 \pm 0.004^{\mathrm{a}}$ & $0.067 \pm 0.005^{\mathrm{bc}}$ \\
\hline & 30 & $0.063 \pm 0.004^{\mathrm{a}}$ & $0.066 \pm 0.002^{\mathrm{a}}$ & $0.071 \pm 0.004^{\mathrm{b}}$ & $0.072 \pm 0.003^{\mathrm{a}}$ & $0.077 \pm 0.003^{\mathrm{b}}$ & $0.077 \pm 0.003^{\mathrm{a}}$ & $0.080 \pm 0.007^{\mathrm{a}}$ \\
\hline & 60 & $0.063 \pm 0.004^{\mathrm{a}}$ & $0.064 \pm 0.002^{\mathrm{a}}$ & $0.066 \pm 0.003^{\mathrm{ac}}$ & $0.082 \pm 0.008^{\mathrm{a}}$ & $0.082 \pm 0.002^{\mathrm{ac}}$ & $0.076 \pm 0.004^{\mathrm{a}}$ & $0.082 \pm 0.005^{\mathrm{ad}}$ \\
\hline \multirow[t]{4}{*}{$\mathrm{Ca}$} & 0 & $0.095 \pm 0.003^{\mathrm{a}}$ & $0.096 \pm 0.002^{\mathrm{c}}$ & $0.077 \pm 0.002^{\mathrm{c}}$ & $0.084 \pm 0.002^{b}$ & $0.081 \pm 0.002^{\mathrm{b}}$ & $0.080 \pm 0.004^{\mathrm{b}}$ & $0.083 \pm 0.003^{b}$ \\
\hline & 16 & $0.095 \pm 0.003^{\mathrm{a}}$ & $0.100 \pm 0.003^{\mathrm{b}}$ & $0.084 \pm 0.005^{\mathrm{bc}}$ & $0.098 \pm 0.006^{\mathrm{ab}}$ & $0.095 \pm 0.004^{\mathrm{ab}}$ & $0.095 \pm 0.001^{\mathrm{ab}}$ & $0.094 \pm 0.001^{\mathrm{a}}$ \\
\hline & 30 & $0.095 \pm 0.003^{\mathrm{a}}$ & $0.104 \pm 0.005^{\mathrm{abc}}$ & $0.093 \pm 0.003^{b}$ & $0.103 \pm 0.004^{\mathrm{a}}$ & $0.096 \pm 0.002^{\mathrm{a}}$ & $0.097 \pm 0.003^{\mathrm{ab}}$ & $0.098 \pm 0.004^{\mathrm{a}}$ \\
\hline & 60 & $0.095 \pm 0.003^{\mathrm{a}}$ & $0.111 \pm 0.005^{\mathrm{a}}$ & $0.100 \pm 0.005^{\mathrm{a}}$ & $0.098 \pm 0.001^{\mathrm{a}}$ & $0.106 \pm 0.007^{\mathrm{a}}$ & $0.104 \pm 0.010^{\mathrm{a}}$ & $0.096 \pm 0.003^{\mathrm{a}}$ \\
\hline \multirow[t]{4}{*}{$\mathrm{Mg}$} & 0 & $0.096 \pm 0.001^{\mathrm{a}}$ & $0.096 \pm 0.001^{b}$ & $0.093 \pm 0.003^{c}$ & $0.091 \pm 0.002^{\mathrm{b}}$ & $0.087 \pm 0.001^{\mathrm{c}}$ & $0.090 \pm 0.002^{b}$ & $0.093 \pm 0.002^{\mathrm{d}}$ \\
\hline & 16 & $0.096 \pm 0.001^{\mathrm{a}}$ & $0.101 \pm 0.003^{b}$ & $0.106 \pm 0.003^{b}$ & $0.114 \pm 0.012^{\mathrm{ab}}$ & $0.100 \pm 0.002^{b}$ & $0.104 \pm 0.005^{\mathrm{a}}$ & $0.103 \pm 0.003^{c}$ \\
\hline & 30 & $0.096 \pm 0.001^{\mathrm{a}}$ & $0.125 \pm 0.001^{\mathrm{a}}$ & $0.132 \pm 0.010^{\mathrm{ab}}$ & $0.123 \pm 0.004^{\mathrm{a}}$ & $0.113 \pm 0.007^{b}$ & $0.109 \pm 0.003^{\mathrm{a}}$ & $0.116 \pm 0.003^{b}$ \\
\hline & 60 & $0.096 \pm 0.001^{\mathrm{a}}$ & $0.136 \pm 0.003^{\mathrm{a}}$ & $0.138 \pm 0.003^{\mathrm{a}}$ & $0.133 \pm 0.003^{\mathrm{a}}$ & $0.123 \pm 0.005^{\mathrm{a}}$ & $0.114 \pm 0.006^{\mathrm{a}}$ & $0.125 \pm 0.001^{\mathrm{a}}$ \\
\hline
\end{tabular}

Concentrations of an element in different FYM treatments are significantly different $(\mathrm{P}<0.05)$ at a given sampling time if they are followed by different alphabet

Table 8 Net changes in the concentration of soil organic C, total N, P, K (mg/100 g) under different FYM treatments after 3 years of cropping

\begin{tabular}{|c|c|c|c|c|c|c|c|c|}
\hline \multirow{2}{*}{$\begin{array}{l}\text { FYM treatment (t/ } \\
\text { ha/crop-season) }\end{array}$} & \multicolumn{2}{|l|}{ Organic C } & \multicolumn{2}{|l|}{ Total N } & \multicolumn{2}{|l|}{ Total P } & \multicolumn{2}{|l|}{ Total K } \\
\hline & Mullasar & Mallasar & Mullasar & Mallasar & Mullasar & Mallasar & Mullasar & Mallasar \\
\hline 0 & -0.29040 & -0.50280 & -0.01998 & -0.01404 & -0.00678 & -0.00037 & -0.02651 & -0.00422 \\
\hline 16 & -0.08640 & -0.17880 & -0.00810 & -0.00414 & -0.00029 & 0.00458 & -0.02390 & -0.01024 \\
\hline 30 & 0.29760 & 0.21720 & -0.00018 & 0.01566 & 0.00486 & 0.00816 & 0.00683 & 0.00040 \\
\hline 60 & 0.52560 & 0.19320 & 0.04134 & 0.03546 & 0.00751 & 0.01164 & 0.00643 & 0.00329 \\
\hline
\end{tabular}


Table 9 FYM inputs and yields reported in other studies and the present present

\begin{tabular}{|c|c|c|c|c|c|}
\hline S. no & $\begin{array}{l}\text { Quantity of } \\
\text { FYM (t/ha) }\end{array}$ & Crop & Location & Yield (kg/ha) & References \\
\hline \multirow[t]{2}{*}{1} & 15 & Rice & Nepal hills & $1500-2200$ & \multirow[t]{2}{*}{ Sherchand et al. (1999) } \\
\hline & 15 & Wheat & Nepal hills & $3000-4500$ & \\
\hline \multirow[t]{7}{*}{2} & 2 & Wheat & \multirow[t]{7}{*}{ Garhwal Himalaya, India } & 398 & \multirow[t]{7}{*}{ Tripathi and Sah (2001) } \\
\hline & 2.1 & Finger millet & & 755 & \\
\hline & 2.4 & Barnyard millet & & 607 & \\
\hline & 0.4 & Soybean & & 531 & \\
\hline & 2.7 & Potato & & 1047 & \\
\hline & $1.7-5.8$ & Pea & & $356-742$ & \\
\hline & 2 & French bean & & 798 & \\
\hline \multirow[t]{4}{*}{3} & 0 & Sorghum & \multirow[t]{4}{*}{ Africa } & 3500 & \multirow[t]{4}{*}{ Alemu and Bayu (2005) } \\
\hline & 5 & Sorghum & & 3900 & \\
\hline & 10 & Sorghum & & 4400 & \\
\hline & 15 & Sorghum & & 4400 & \\
\hline \multirow[t]{3}{*}{4} & 0 & Sorghum & \multirow[t]{3}{*}{ West Africa } & $408-1160$ & \multirow[t]{3}{*}{ Ouédraogo et al. (2001) } \\
\hline & 5 & Sorghum & & 1689 & \\
\hline & 10 & Sorghum & & 1380 & \\
\hline \multirow[t]{2}{*}{5} & 10 & & \multirow{2}{*}{$\begin{array}{l}\text { Rainfed agroecosystem in Central } \\
\text { Himalaya }\end{array}$} & - & \multirow[t]{2}{*}{ Maikhuri et al. (2001) } \\
\hline & $15-35$ & & & & \\
\hline 6 & 5 & & North Nigeria, Africa & - & Agbenin and Goladi (1997) \\
\hline \multirow[t]{4}{*}{7} & 20 & Tomato & Himachal Pradesh & - & Sharma and Sharma (2004) \\
\hline & 0 & Carrot & \multirow[t]{3}{*}{ Himachal Pradesh } & - & \multirow[t]{3}{*}{ Sharma et al. (2003) } \\
\hline & 10 & Carrot & & - & \\
\hline & 12 & Carrot & & - & \\
\hline \multirow[t]{2}{*}{8} & 10 (oak) & Wheat & \multirow[t]{2}{*}{ central Himalaya } & 582 & \multirow{2}{*}{$\begin{array}{l}\text { Rao et al. (2005); Saxena et al. } \\
\text { (2005) }\end{array}$} \\
\hline & 10 (Pine) & Wheat & & 467 & \\
\hline \multirow[t]{3}{*}{9} & $15-16.5$ & - & Himalaya $1100-1850 \mathrm{msl}$ & - & \multirow{3}{*}{$\begin{array}{l}\text { Sen et al. (1997); Saxena et al. } \\
\text { (2005) }\end{array}$} \\
\hline & $18.3-27.4$ & - & Himalaya $1850-2400 \mathrm{msl}$ & - & \\
\hline & $16.8-32.4$ & - & Himalaya $2400-2600 \mathrm{msl}$ & - & \\
\hline 10 & 30.7 & Paddy & Langasu-Uttaron village of Cha- & 2620 & Chandra et al. (2011a) \\
\hline & 30.0 & Paddy + others & moli district, Garhwal Himalaya & 3248 & \\
\hline & 27.7 & Barnyard millet & & 1524 & \\
\hline & 12.3 & Foxtail millet & & 623 & \\
\hline & 9.1 & Wheat + mustard & & 1306 & \\
\hline & 4.4 & Barley & & 1036 & \\
\hline & 14.4 & Finger millet & & 2344 & \\
\hline & 12.4 & Finger millet + Blackgram (mixed) & & 2482 & \\
\hline & 12.5 & Finger millet + legumes (mixed) & & 2410 & \\
\hline & - & Legumes (mixed) & & 2446 & \\
\hline & - & Blackgram & & 1900 & \\
\hline & - & Soybean & & 3104 & \\
\hline & 1.3 & Mustard & & 456 & \\
\hline 11 & 24 & Paddy & Chandrapuri village, Rudraprayag & $4946 \pm 492$ & Dinakaran et al. (2019) \\
\hline & 15 & Wheat + mustard & district, Garhwal Himalaya & $3100 \pm 204$ & \\
\hline & 60 & Rice & & 1666.67 & \\
\hline 12 & 0 & Rice & Langasu-Uttaron village of Cha- & $2065-2175$ & Present study \\
\hline & 16 & Rice & moli district, Garhwal Himalaya & $2333-2432$ & \\
\hline & 30 & Rice & & $2475-2602$ & \\
\hline & 60 & Rice & & $3079-3361$ & \\
\hline
\end{tabular}


Table 9 (continued)

\begin{tabular}{|c|c|c|c|c|c|}
\hline S. no & $\begin{array}{l}\text { Quantity of } \\
\text { FYM (t/ha) }\end{array}$ & Crop & Location & Yield (kg/ha) & References \\
\hline & 0 & Wheat & \multirow{4}{*}{$\begin{array}{l}\text { Langasu-Uttaron village of Cha- } \\
\text { moli district, Garhwal Himalaya }\end{array}$} & $865-1078$ & \multirow[t]{4}{*}{ Present study } \\
\hline & 16 & Wheat & & $932-1182$ & \\
\hline & 30 & Wheat & & $1481-1693$ & \\
\hline & 60 & Wheat & & 1759-2555 & \\
\hline & 0 & Blackgram & \multirow{4}{*}{$\begin{array}{l}\text { Langasu-Uttaron village of Cha- } \\
\text { moli district, Garhwal Himalaya }\end{array}$} & $1776-1808$ & \multirow[t]{4}{*}{ Present study } \\
\hline & 16 & Blackgram & & $1822-1840$ & \\
\hline & 30 & Blackgram & & 1894-1941 & \\
\hline & 60 & Blackgram & & 2084-2094 & \\
\hline
\end{tabular}

Acknowledgements The authors are thankful to the residents of the study area for their participation in the research work and to the TSBF/ UNEP/GEF for providing partial financial support.

Funding TSBF/UNEP/GEF for providing partial financial support.

\section{Compliance with ethical standards}

Conflict of interest The authors declare that they have no conflict of interests.

\section{References}

Abe S, Hashimoto S, Umezane T, Yamaguchi T, Yamamoto S, Yamada S, Endo T, Nakata N (2016) Excessive application of farmyard manure reduces rice yield and enhances environmental pollution risk in paddy fields. Arch Agron Soil Sci 62:1208-1221

Agbenin JO, Goladi JT (1997) Carbon, nitrogen and phosphorus dynamics under continuous cultivation as influenced by savanna of northern Nigeria. Agr Ecosys Environ 36:17-24

Alemu G, Bayu W (2005) Effect of farm yard manure and combined $\mathrm{N}$ and $\mathrm{P}$ fertilizer on Sorghum and soil characteristics in northern Ethiopia. J Sustain Agric 26:23-41

Allen SE (1974) Chemical analysis of ecological materials. Blackwell Scientific Publications, Oxford

Anderson JM, Ingram JSI (1989) Tropical soil biology and fertility: A handbook of methods. CAB, International, Wallingford, Oxon

Bhadauria T, Kumar P, Maikhuri R, Saxena KG (2014) Effect of application of vermicompost and conventional compost derived from different residues on pea crop production and soil faunal diversity in agricultural system in Garhwal Himalayas India. Nat Sci 6:433-446

Bhandari AL, Ladha JK, Pathak H, Padre AT, Dawe D, Gupta RK (2002) Yield and soil nutrient changes in a long-term rice-wheat rotation in India. Soil Sci Soc Am J 66:162-170

Blanchet G, Gavazov K, Bragazza L, Sinaj S (2016) Responses of soil properties and crop yields to different inorganic and organic amendments in a Swiss conventional farming system. Agr Ecosyst Environ 230:116-126

Chandra A (2007) Traditional agrodiversity management in central Himalayan village ecosystem. Ph.D. Thesis, University of Delhi, Delhi, India

Chandra A, Kandari LS, Payal KC, Maikhuri RK, Rao KS, Saxena KG (2010a) Conservation and sustainable management of traditional ecosystems in Garhwal Himalaya, India, New York. Sci J 3(2):71-77

Chandra A, Pardha-Saradhi P, Maikhuri RK, Saxena KG, Rao KS (2010b) Assessment of monetary budget in traditional agrodiversity management: a case study of central Himalayan village ecosystem. Phytomorphology 60:137-149

Chandra A, Pardha-Saradhi P, Maikhuri RK, Saxena KG, Rao KS (2011a) Traditional agrodiversity management: a case study of central Himalayan village ecosystem. J Mount Sci 08:62-74

Chandra A, Pardha-Saradhi P, Rao KS, Saxena KG, Maikhuri RK (2011b) An investigation into the energy use in relation to yield of traditional crops in central Himalayas, India. Biomass Bioenergy 35:2044-2052

Chandra A, Kandari LS, Rao KS, Saxena KG (2011c) Assessment of socio-economical status and its impact on land use management in Central Himalaya. Asian J Agric Res 5(4):234-242

Chandra A, Kandari LS, Negi VS, Maikhuri RK, Rao KS (2013) Role of intercropping on production and land use efficiency in the central Himalaya, India. Environ Int J Sci Technol 8:105-113

Datta A, Mandal B, Basak N, Badole S, Chaitanya K, Majumder S, Thakur N, Kumar P, Kachroo D (2018) Soil carbon pools under long-term rice-wheat cropping system in Inceptisols of Indian Himalayas. Arch Agron Soil Sci 64:1315-1320

Dinakaran J, Chandra A, Chamoli KP, Deka J, Rao KS (2018) Soil organic carbon stabilization changes with an altitude gradient of land cover types in central Himalaya, India. Catena 170:374-385

Dinakaran J, Chandra A, Vikram K, Chamoli K, Tambat S, Rao KS (2019) Responses of soil carbon, nitrogen, microbial activity, bacterial community composition and grain yield to farmyard manure amendments in a rainfed agriculture (Paddy) system of Himalaya. Vegetos 32:620-634

Gomez K, Gomez A (1984) Statistical procedures for agricultural research. Wiley, New York

Gopalan C, Ramashastri BV, Balasubramaninan SC, Rao BSN, Deosthale YG, Pant KC (2004) Nutritive value of indian foods. National Institute of Nutrition, Hyderabad

Gupta AP, Narwal RP, Antil RS (2003) Influence of soil organic matter on the productivity of pearl millet-wheat cropping system. Arch Agron Soil Sci 49:325-332

Han P, Zhang W, Wang G, Sun W, Huang Y (2016) Changes in soil organic carbon in croplands subjected to fertilizer management: a global meta-analysis. Sci Rep 6:27199. https://doi. org/10.1038/srep27199

Hartmann M, Frey B, Mayer J, Mäder P, Widmer F (2015) Distinct soil microbial diversity under long-term organic and conventional farming. ISME J 9:1177-1194 
Jackson ML (2005) Soil chemical analysis, 2nd edn. Parallel Press, University of Wisconsin, Madison Lib, Wisconsin

Kiani MJ, Abbasi MK, Rahim N (2005) Use of organic manure with mineral $\mathrm{N}$ fertilizer increases wheat yield at Rawalakot Azad Jammu and Kashmir. Arch Agron Soil Sci 51:299-309

Kundu S, Bhattacharya R, Prakash V, Gupta HS, Pathak H, Ladha JK (2007) Longterm yield trend and sustainability of rainfed soybeanwheat system through farmyard manure application in a sandy loam soil of the Indian Himalayas. Biol Fertil Soils 43:271-280

Kundu S, Bhattacharya R, Prakash V, Ghosh BN, Gupta HS (2007) Carbon sequestration and relationship between carbon additions and storage under rainfed soybean-wheat rotation in a sandy loam soil of the Indian Himalayas. Soil Tillage Res 92:87-92

Ladha JK, Dawe D, Pathak H, Padre AT, Yadav RL, Singh B, Singh Y, Singh Y, Singh P, Kundu AL, Sakal R, Ram N, Regmi AP, Gami SK, Bhandari AL, Amin R, Yadav CR, Bhattarai EM, Das S, Aggarwal HP, Gupta RK, Hobbs PR (2003) How extensive are yield declines in long-term rice-wheat experiments in Asia? Field Crop Res 81:159-180

Laishram J, Maikhuri RK, Rao KS, Saxena KG (2009) Land use intensification in Indian Himalaya: Meaning, measurement and implications. Int J Ecol Environ Sci 35:35-52

Laishram J, Saxena KG, Rao KS (2020) Rice cultivar diversity, associated Indigenous knowledge and management practices in a lowland village landscape from north-eastern India. Vegetos $33: 172-186$

Lal R (2004) Soil carbon sequestration impacts on global climate change and food security. Science 304:1623-1627

Liu E, Yan C, Mei X, Zhang Y, Fan T (2013) Long-term effect of manure and fertilizer on soil organic carbon pools in dryland farming in northwest China. PLoS ONE 8:e56536

Luo X, Fu X, Yang Y, Cai P, Peng S, Chen W, Huang Q (2016) Microbial communities play important roles in modulating paddy soil fertility. Sci Rep 6:20326. https://doi.org/10.1038/srep20326

Mahanta D, Bhattacharyya R, Gopinath K, Tuti M, Mina B, Pandey B, Mishra P, Bisht J, Srivastva A, Bhatt J (2013) Influence of farmyard manure application and mineral fertilization on yield sustainability, carbon sequestration potential and soil property of Gardenpea-French bean cropping system in the Indian Himalayas. Sci Hortic 164:414-427

Maikhuri RK, Rao KS, Semwal RL (2001) Changing scenario of Himalayan agroecosystems: loss of agrobiodiversity, an indicator of environmental change in Central Himalayas. Environ 21:23-39

Maikhuri RK, Rawat LS, Semwal RL, Rao KS, Saxena KG (2015) Organic farming in Uttarakhand Himalaya, India. Int J Ecol Environ Sci 41:161-176

Mandal KG, Hati KM, Misra AK (2009) Biomass yield and energy analysis of soybean production in relation to fertilizer-NPK and organic manure. Biomass Bioenergy 33:1670-1679

Meertens HCC, Kajiu GJ, Ndege LJ, Enserink HJ, Brouwer J (2003) Evalution of on-farm soil fertility resource in the rainfed lowland rice fields of Sukumaland. Tanzania Exp Agric 39:65-79

Mushtaqe S, Hafeez M, Khair SM (2007) Determination of optimal input usage into the wheat production for Kareze irrigation in the BalaChistan, Pakistan. Asian J Plant Sci 6:809-814

Nambiar KKM (1994) Soil fertility and crop productivity under longterm fertilizer use in India. ICAR, New Delhi

Nayak D, Babu Y, Adhya T (2007) Long-term application of compost influences microbial biomass and enzyme activities in a tropical Aeric Endoaquept planted to rice under flooded condition. Soil Biol Biochem 39:1897-1906

Negi VS, Maikhuri RK, Rawat LS, Bahuguna A (2009) Traditional agriculture in transition: a case of Har-ki Doon Valley (Govind Pashu Vihar Sanctury and National Park) in central Himalaya. Int J Sustain Dev World Ecol 16:313-321
Ouédraogo E, Mando A, Zombré NP (2001) Use of compost to improve soil properties and crop productivity under low input agricultural system in West Africa. Agr Ecosys Environ 84:259-266

Rao KS, Nautiyal S, Maikhuri RK, Saxena KG (2005) Resource flows of villages with contrasting lifestyles in Nanda Devi Biosphere Reserve, Central Himalaya, India. J Mount Sci 2:271-293

Rao KS, Saxena KG, Tiwari BK (2016) Biodiversity, climate change and socio-economic development in the Indian Himalaya: an overview. Bishen Singh Mahendra Pal Singh, Dehradun

Rautaray SK, Ghosh BC, Mittra BN (2003) Effect of fly ash, organic wastes and chemical fertilizers on yield, nutrient uptake, heavy metal content and residual fertility in a rice-mustard cropping sequence under acid lateritic soils. Bioresour Technol 90:275-283

Saxena KG, Rao KS (2016) Soil biodiversity: inventory, functions and management. Bishen Singh Mahendra Pal Singh, Dehradun

Saxena KG, Maikhuri RK, Rao KS (2005) Changes in agricultural biodiversity: implications for sustainable livelihood in the Himalaya. J Mount Sci 2:23-31

Semwal RL, Maikhuri RK (1996) Agroecosystem analysis of Garhwal Hiamalaya. Biol Agric Hort 13:267-289

Sen KK, Rao KS, Saxena KG (1997) Soil erosion due to settled upland farming in the Himalaya: a case study in Pranmati watershed. Int J Sustain Dev World Ecol 4:65-74

Shah Z, Ahmad MI (2006) Effect of integrated use of farm yard manure and urea on yield and nitrogen uptake of wheat. J Agric Biol Sci $1: 60-65$

Sharma A, Sharma JJ (2004) Influence of organic and inorganic sources of nutrients on tomato (Lycopersicon esculentum) under high hill dry temperature conditions. Indian J Agric Sci 74:465-467

Sharma A, Sharma RP, Sood S, Sharma JJ (2003) Influence of integrated use of nitrogen, phosphorus, potassium and farmyard manure on yield-attributing traits and marketable yield of carrot (Daucuscarota) under high hills dry temperate condition of northwestern Himalayas. Indian J Agric Sci 73:500-503

Sherchand DP, Pilbeam CJ, Gregory PL (1999) Response of wheat/rice and maize/millet system to fertilizer and manure applications in mid-hills of Nepal. Exp Agric 35:1-13

Shrestha KK, Ladha JK, Gami SK (2006) Total and organic soil carbon in cropping systems of Nepal. Nut Cycl Agroecosyst 75:257-269

Singh H, Mishra D, Nahar NM (2002) Energy use pattern in production agriculture of a typical village in Arid zone India. Energy Convers Manag 43:2275-2286

Singh Y, Singh B, Ladha JK, Khind CS, Gupta RK, Meelu OP, Pasuquin E (2004) Long-term effect of organic inputs on yield and soil fertility in rice -wheat rotation. Soil Sci Soc Am J 68:845-853

Singh S, Ghoshal N, Singh KP (2007) Synchronizing nitrogen availability through application of organic inputs of varying resource quality in a tropical dryland agroecosystem. Appl Soil Ecol 36:164-175

Singh D, Akhtar Z, Gupta S, Srivastava A, Chakraborty M (2017) Production strategies of organic basmati rice in Tarai region of Uttarakhand, India. Org Agric 7:21-30

Tripathi RS, Sah VK (2001) Material and energy flows in high-hill, mid-hill and valley farming systems of Garhwal Himalaya. Agr Ecosys Environ 86:75-91

Walkley A, Black LA (1934) An examination of the degtjareff method for determining soil organic matter and a proposed modification of the chromic acid titration method. Soil Sci 37:29-38

Wani SP, Rupela OP, Lee K (1995) Sustainable agriculture in the semiarid tropics through biological nitrogen fixation in grain legumes. Plant Soil 174:29-49

Yadav RL, Yadav DJ, Singh RM, Kumar A (1998) Long term effects of inorganic fertilizer inputs on crop productivity in a rice-wheat cropping system. Nut Cycling Agroecosyst 51:1385-1314

Zingore S, Muriwina HK, Delve RJ, Gillar KE (2007) Influence nutrient management strategies on variability of soil fertility, crop yield 
and nutrient balances on small holder farms in Zimbabwe. Agr Ecosys Environ 119:112-126
Publisher's Note Springer Nature remains neutral with regard to jurisdictional claims in published maps and institutional affiliations. 